\title{
Crossrail project: commercial aspects of works contracts for London"s Elizabeth line
}

1 David Morrice BSC, MRICS

Delivery Contracts Director, Crossrail Limited, UK
2 Megan Hands LLB

Project Solicitor, Crossrail Limited, UK
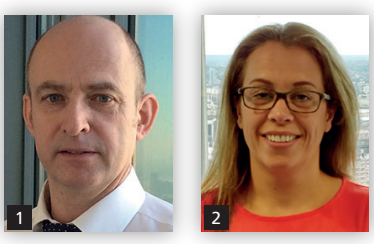

Choosing the right commercial arrangements between the client and contractors was critical to successful delivery of the $\mathbf{f 1 4 . 8}$ billion Crossrail project to deliver the Elizabeth line east-west railway across London. This paper explains how delivery organisation Crossrail Limited used the NEC3: Engineering and Construction Contract to procure $\mathbf{f 6 . 5}$ billion of main works packages from a wide range of major contractors. The objective was to ensure a fair balance of risk and reward, to allow changes to be accommodated and to enable programme challenges to be addressed as they arose. The paper also deals with the client's approach to commercial management during the course of the 6 year programme, through to final settlement of accounts with contractors.

\section{Crossrail works contracts}

The Crossrail works contracts to deliver the new Elizabeth line east-west railway across London, UK, were mostly let under NEC3: Engineering and Construction Contract (ECC) Option C (target contract with activity schedule) (NEC, 2013) terms.

The works contracts can be separated into six distinct categories.

- Early enabling works - comprising mainly demolition and utility moves with a total cost of approximately $£ 90$ million. The majority of these works was carried out through 22 separate NEC3 ECC Option A (priced contract with activity schedule) contracts. They were developed ahead of the main works contracts, which are the main focus of this paper (Figure 1).

- Tunnelling contracts - comprising all running tunnels (including purchase of tunnel boring machines) and sprayed concrete lining, with a total combined value of approximately $£ 2.4$ billion. These were let as five separate contracts: C300, western running tunnels and sprayed concrete enlargements at stations; C305, eastern running tunnels; C310, Thames tunnel; C510, eastern sprayed concrete enlargements at stations; and C315, Connaught tunnel refurbishment.

- General civil engineering contracts - including many of the major portals and shafts, marine transport of excavated material (let under NEC3 ECC Option B (priced contract with bill of quantities)), depot and siding works. These were let under 11 separate contracts with a combined value of approximately $£ 600$ million.

- Station advanced works packages - six separate contracts with a combined value of approximately $£ 300$ million. These mainly comprise piling and diaphragm wall station boxes that have an interface with the tunnelling and therefore needed to be constructed ahead of the tunnels.

- Station construction and fit-out - this was let under eight separate contracts with a combined value of approximately
$£ 2.3$ billion. One of these (C435, Farringdon) differs from the others in that it includes the sprayed concrete enlargements at Farringdon as well as the station construction and fit-out.

- Systems contracts - including track, ventilation, power, signalling, communications and platform doors (carried out under NEC3 ECC Option A), which were let as six contracts with a combined value of approximately $£ 900$ million.

In total there are 36 main works contracts (see Table 1) with a total value of approximately $£ 6.5$ billion. The number of contracts reflects the complex nature of the Crossrail programme and the strategy of its delivery organisation, Crossrail Limited, to expose and actively manage the critical interface risks rather than pass them down into the supply chain.

\section{Main works contractors}

A programme on the scale of Crossrail obviously attracted most of the major UK contractors, but it also attracted a good number of European contractors together with their senior management

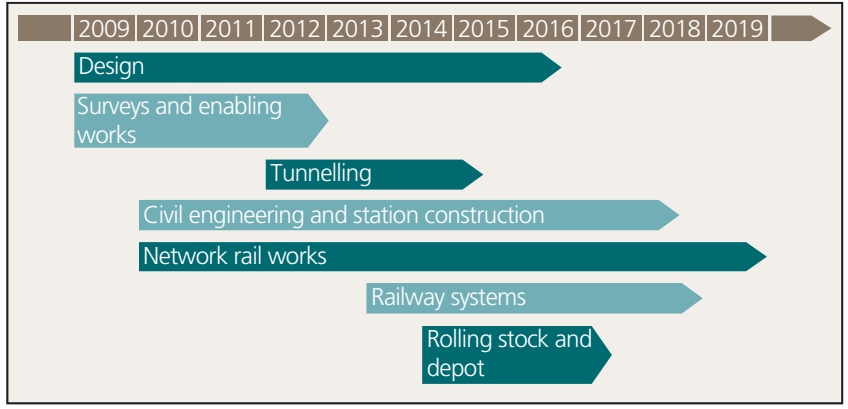

Figure 1. Timeline of Crossrail contracts 
Table 1. List of major contracts

\begin{tabular}{|c|c|c|c|}
\hline $\begin{array}{l}\text { Contract } \\
\text { reference }\end{array}$ & $\begin{array}{l}\text { NEC3 ECC } \\
\text { Option }\end{array}$ & Contract name & Contractor \\
\hline C330 & C & Royal Oak portal (advanced civils) - phase 1 & Costain/Skanska joint venture \\
\hline C248 & C & $\begin{array}{l}\text { Pudding Mill Lane portal (civils tunnel boring machine reception } \\
\text { chamber and } 400 \mathrm{kV} \text { cable) }\end{array}$ & Costain/Skanska joint venture \\
\hline C272 & C & $\begin{array}{l}\text { Paddington integrated project - main works (including } \\
\text { mechanical and electrical) }\end{array}$ & Carillion \\
\hline C421 & C & Tottenham Court Road (piling and diaphragm walling) & Balfour Beatty/Morgan Sindall/Ninci joint venture \\
\hline C806 & A & Wallasea temporary jetty & BAM \\
\hline C430 & C & Farringdon station (shaft piling and diaphragm walling) & Laing O'Rourke/Strabag joint venture \\
\hline C511 & C & Whitechapel station (piling and diaphragm walling) & BAM/Kier joint venture \\
\hline C411 & C & Bond Street station (piling and diaphragm walling) & Costain/Skanska joint venture \\
\hline C501 & C & Liverpool Street station (piling and diaphragm walling) & BAM/Kier joint venture \\
\hline C503 & C & Liverpool Street station (civils advance works package 1) & Vinci \\
\hline C315 & C & Connaught tunnel refurbishment and surface rail works & Vinci \\
\hline C310 & C & $\begin{array}{l}\text { Drive } \mathrm{H} \text { (Thames tunnel) including North Woolwich and } \\
\text { Plumstead portals }\end{array}$ & Hochtief/Murphy joint venture \\
\hline $\mathrm{C} 807$ & B & Marine transportation & BAMNan Oord joint venture \\
\hline C305 & C & Eastern running tunnels & Dragados/Sisk joint venture \\
\hline $\begin{array}{l}\text { C } 300 \text { and } \\
\text { C410 }\end{array}$ & $\mathrm{C}$ & $\begin{array}{l}\text { Western running tunnels and Bond Street/Tottenham Court Road } \\
\text { sprayed concrete lining }\end{array}$ & BAM/Ferrovial/Kier joint venture \\
\hline C340 & C & Victoria Dock portal (civil works) & Vinci \\
\hline C510 & C & $\begin{array}{l}\text { Liverpool Street and Whitechapel station (early access shafts and } \\
\text { sprayed concrete lining works) }\end{array}$ & $\begin{array}{l}\text { Balfour Beatty/Morgan Sindall/Ninci/BeMo joint } \\
\text { venture }\end{array}$ \\
\hline C350 & C & Pudding Mill Lane portal (main civils works) & Morgan Sindall \\
\hline $\mathrm{C} 828$ & C & Ilford Yard stabling sidings & VolkerFitzpatrick \\
\hline C336 & C & Paddington New Yard project & Costain \\
\hline C360 & C & Eleanor Street and Mile End Park shafts (civils works) & Costain/Skanska joint venture \\
\hline C520 & C & Custom House (main station works) & Laing O'Rourke \\
\hline C405 & $\mathrm{C}$ & $\begin{array}{l}\text { Paddington station (main station works, fit-out plus mechanical } \\
\text { and electrical) }\end{array}$ & Costain/Skanska joint venture \\
\hline C412 & C & $\begin{array}{l}\text { Bond Street station (main station works, fit-out plus mechanical } \\
\text { and electrical) }\end{array}$ & Costain/Skanska joint venture \\
\hline C422 & C & $\begin{array}{l}\text { Tottenham Court Road (main station works, fit-out plus } \\
\text { mechanical and electrical) }\end{array}$ & Laing O'Rourke \\
\hline C435 & $C$ & $\begin{array}{l}\text { Farringdon station (main station works, tunnels, fit-out plus } \\
\text { mechanical and electrical) }\end{array}$ & BAM/Ferrovial/Kier joint venture \\
\hline C502 & C & $\begin{array}{l}\text { Liverpool Street station (main station works, fit-out plus } \\
\text { mechanical and electrical) }\end{array}$ & Laing O'Rourke \\
\hline C512 & C & $\begin{array}{l}\text { Whitechapel station (main station works, fit-out plus mechanical } \\
\text { and electrical) }\end{array}$ & Balfour Beatty/Morgan Sindall/Ninci joint venture \\
\hline C530 & C & Plumstead and Woolwich fit-outs & Balfour Beatty \\
\hline C610 & C & Track, overhead line equipment and logistics & Alstom/TSO/Costain joint venture \\
\hline C620 & C & Railway signalling and control (central operating section) & Siemens/Invensys joint venture \\
\hline C631 & A & Platform screen doors & Knorr Bremse \\
\hline C644 & C & Central section traction power infrastructure & Alstom/Costain joint venture \\
\hline C650 & C & Non-traction high voltage power & Alstom/Costain joint venture \\
\hline C660 & C & Communications and controls systems & Siemens \\
\hline C695 & $\mathrm{C}$ & Plumstead maintenance facility & Alstom/TSO/Costain joint venture \\
\hline
\end{tabular}


and professional staff. This could well have been as a result of the difficulties being experienced in the home markets at the time Crossrail was bid, together with a desire to expand into the UK market, usually as a part of a UK-based joint venture.

Whatever the reason, the injection of European expertise has been of great benefit to Crossrail. The major contractors, working either alone or in joint ventures, contributing to Crossrail are BAM Nuttall, Ferrovial Agroman, Kier Construction, Dragados, John Sisk, Hochtief Solutions, J. Murphy, Balfour Beatty Civil Engineering, BeMo Tunnelling, Morgan Sindall Construction and Infrastructure, Vinci Construction Grand Projets, Vinci Construction UK, Costain, Skanska Construction UK, Laing O'Rourke Construction, Alstom Transport UK, TSO SAS, Siemens, Invensys Rail, VolkerFitzpatrick and Knorr Bremse Rail Systems (UK).

Many of the contractors have formed unincorporated joint ventures for the Crossrail contracts of two, three or even four parties. This obviously reduces the risk for individual contractors and gives a greater pool of expertise and experience to draw from. From Crossrail Limited's perspective as client, joint ventures can take longer to 'bed down' and establish common processes and systems. Some joint ventures can also struggle with internal governance and decision-making.

\section{NEC contract terms}

A decision to use the NEC3 ECC Option C form of contract was made in late 2008. The main reasons for this were

- it was considered to be supportive of the client's culture and objectives

- it should achieve a fair and sensible allocation of risk

- it would provide robust contract management processes

- it could be used for all Crossrail requirements (by providing a variety of procurement options)

- it is endorsed by the UK Office of Government Commerce, Transport for London and the Institution of Civil Engineers (ICE)

- its use on other major projects such as London 2012 and High Speed One would provide the opportunity to benefit from lessons learned.

Drafting contract terms was led by the client's in-house legal team with a remit of having a 'light touch' approach to the standard NEC forms. The detailed work culminated in a relatively modest number of amendments (Figure 2).

During procurement of the first main works contracts (the tunnels), the client's approach was to use responses from tenderers to develop further its standard conditions of contract. Qualifications put forward within bids were therefore reviewed on the basis of whether such an amendment could and should be accepted as a change to the standard form. There was therefore very little individual negotiation of conditions of contract with individual tenderers.

Thus, upon award of the first main contracts, the standard main civils contract had matured to a point which provided an allocation of risk, which was not only acceptable to the client but also to a significant portion of the construction market at the time. As a result of that process, all further procurement was able to be conducted at the pace required to support the overall project programme because

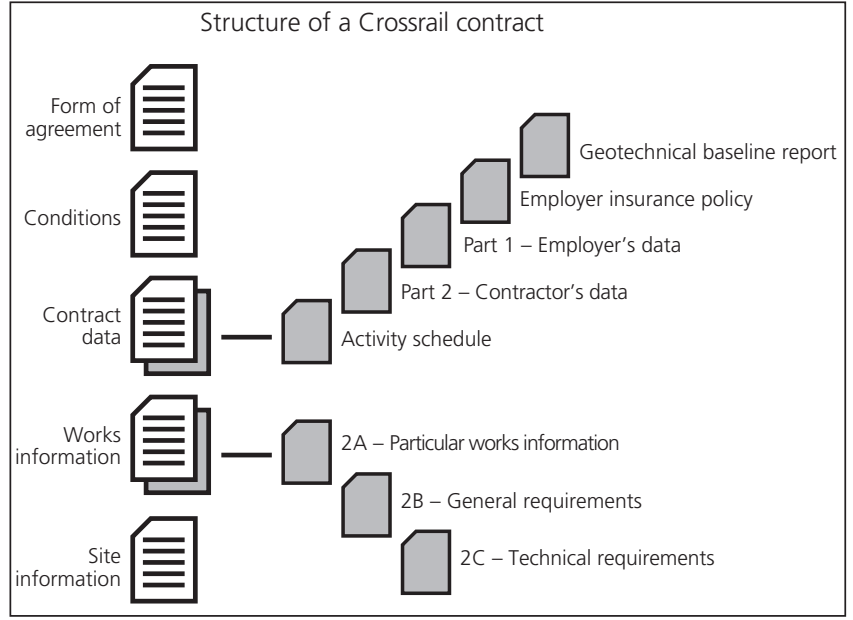

Figure 2. The structure of a Crossrail contract document

a relatively small amount of time was required to be reserved for the negotiation of contract conditions.

\subsection{Commercial strategy}

From a client's perspective, the three most important aspects that drive commercial management and cost control under ECC Option $\mathrm{C}$ are the pain/gain bandings, the approach to disallowed cost and completion/key dates.

Pain/gain share - there are many arguments for and against the multitude of differing pain/gain shares that have been used under ECC Option C. The client considered most of these arguments, consulted with other large clients and contractors and concluded that a simple 50/50 pain/gain share was the most appropriate. No bandings were adopted and pain and gain are both uncapped. The most compelling reasons for using 50/50 are that it is fair and balanced between employer and contractor and is simple to understand. This approach has served the client well to date.

- Cost - under ECC Option C there is sometimes a temptation to place too much focus on disallowing costs when things are going badly or as an alternative to a non-functioning target mechanism - this rarely has the desired effect. The client left the standard NEC disallowed cost and schedule of cost components largely unchanged; the most significant addition was to tweak some heads of disallowed cost to encourage the reporting of defects and therefore a defect-free job at completion. While NEC encourages timely settlement of target cost issues, it does not (in the client's opinion) encourage timely settlement of defined cost to the same extent. The client therefore adopted a deliberate policy of auditing costs contemporaneously and openly so that problems were not stored away, and of reaching firm agreement to cost at significant points through the course of a contract.

- Completion dates - with so many interfaces between contracts, it was essential that contractors achieve interface milestones on time. To embed this in the contracts, the client has extensively used key dates and section completion dates with appropriate damages across all contracts. As time has progressed and the key programme drivers have emerged, this liability regime has been supplemented with programme-driven incentive mechanisms. 
Civil Engineering

Volume 170 Issue CE6
Crossrail project: commercial aspects of works contracts for London's Elizabeth line

Morrice and Hands

\subsection{Contract amendments}

Aspects of the standard ECC Option C that were changed and that are considered material are as follows.

- Compensation events for physical conditions - the physical conditions compensation event was retained but with provision for use of a geotechnical baseline report (GBR), in line with the tunnelling joint code of practice (Association of British Insurers/ British Tunnelling Society, 2003) The GBR fixed the baseline for certain physical conditions, on an objective basis. GBRs were not necessarily factual (in the sense of site information) but established a sensible allocation of risk. Types of conditions not addressed in the GBR fell to the usual NEC mechanism.

- No entitlement to fee on cost that exceeds target - after discussion with other major programmes it was considered appropriate for the client to adopt this to seek to avoid any potential for contractors to gain commercially, even when in a pain situation.

- Payment cycle - a payment cycle was established which reflected the requirements of the then current legislation (Housing Grants Construction and Regeneration Act 1996) and which was also consistent with the client's fair payment commitment for the payment of subcontractors within a 30-day period. The proposed payment cycle granted the client a 16-day period to take certificates through internal finance processes, which was considered to be adequate.
- Retention - neither retention nor retention bonds were utilised in tier 1 contracts. The client relied instead on the use of a performance bond. It was decided that the client should not expressly prohibit the use of retention further down the supply chain as main contractors would be committing to a fair payment charter.

- Right to deduct pain share before completion - it was recognised that, under standard NEC contracts, if costs were to exceed the target at the end of the contract such that there should be a deduction from the contractor for pain share, the client may find itself in a position in which it would be required to take action to recover that pain share. To avoid this situation, the contract was amended to permit the client to deduct pain share in advance of completion.

- Liability caps - following receipt of initial tenders, it was determined that an appropriate cap based on a percentage of the final target price would represent a sensible allocation of risk. This would not drive excessive risk allowances in tender prices while maintaining an adequate incentive on contractors to perform. After consideration of approaches taken on other projects and by other organisations, the client decided to adopt a straightforward approach with one overall liability cap (rather than different caps applying to different types of loss) subject to certain excluded matters. Excluded matters were deliberately retained at a minimum: delay damages, contractor's share and repayment of disallowed cost.

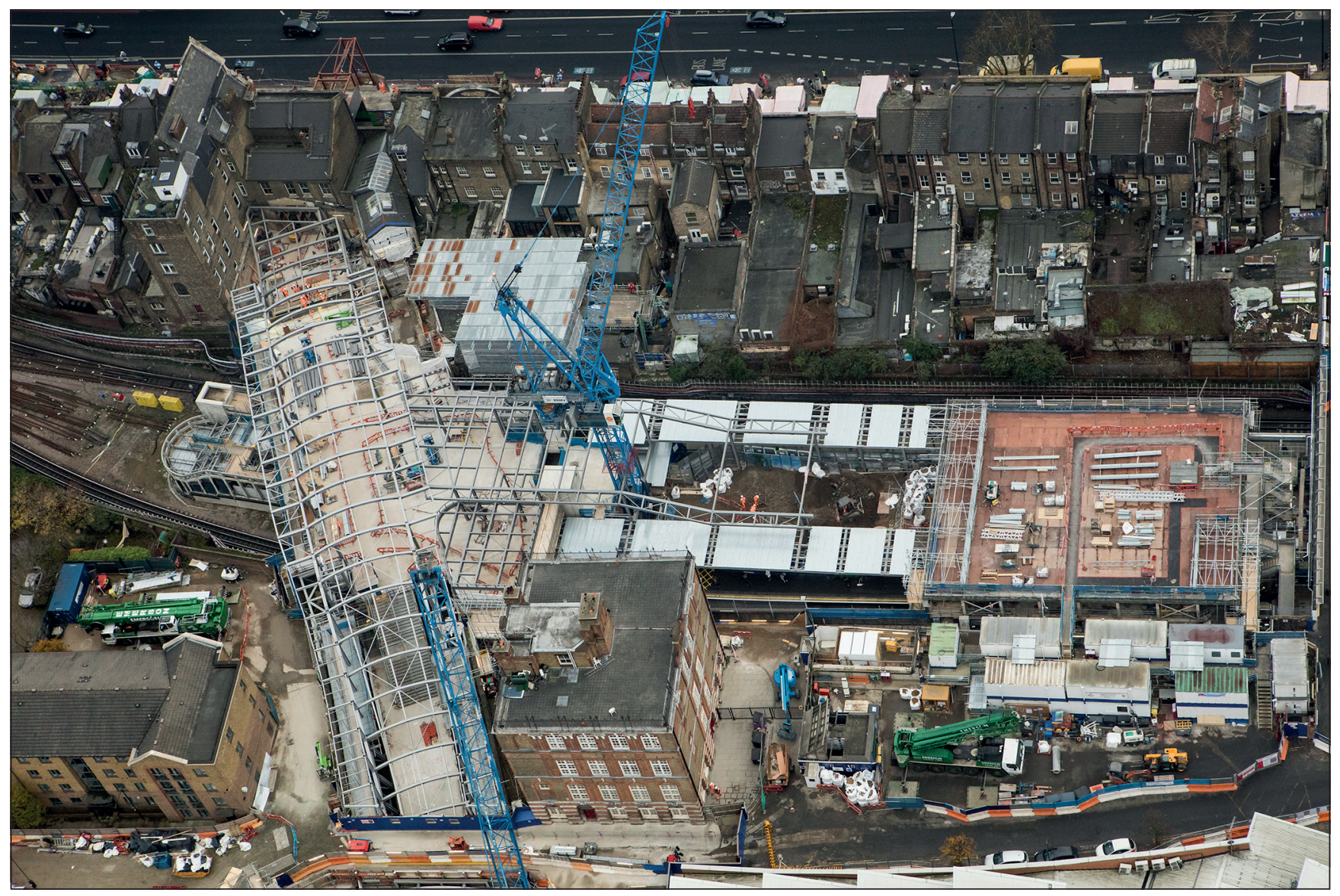

Figure 3. Whitechapel station: construction on a constrained urban site 
- Security/parent company guarantees and bonds - in nearly all circumstances, parent company guarantees were required by the client to be provided by the ultimate parent company of the contractor. Performance bonds of $10 \%$ on default were also required, reducing to $2 \cdot 5 \%$ at completion. On-demand bonds were not sought other than in respect of advance payments for off-site goods and materials.

- Dispute resolution process - the client considered approaches taken on other projects (e.g. the London 2012 independent dispute avoidance panel) and determined that a panel of adjudicators would be the most appropriate option for Crossrail. The panel was established under the auspices of ICE and members were selected in conjunction with ICE to provide the breadth of experience and expertise which would be required for the project. In the event of an adjudication, the parties were to seek to agree an adjudicator from the panel, failing which one would be nominated by ICE. In the latter event, each party was entitled to veto one member of the panel.

- Referral to adjudication was to be preceded by managerial discussions. While this could not exclude a contractor's right to adjudicate at any time, in practice disputes have been the subject of managerial discussions.

- Schedule of cost components - the only significant amendment to the schedule of cost components was the deletion of the working area overhead mechanism whereby contractors are paid a percentage of costs to cover preliminary items. This was deleted to avoid ending up, as a result of the tendering process, with a very high percentage that would skew fee recovery (and therefore the pain/gain mechanism of the contract) and differences of opinion with regard to the coverage of the percentage. Such items are fully paid as part of defined cost.

- Time - a requirement was added for the contractor to take all reasonable steps to mitigate the effect of any compensation event. The acceleration provisions were amended so that the project manager could instruct acceleration (albeit without bringing forward a liability for delay damages). These changes reflected the importance of time and programme to the client.

- Project bank account - the client adopted the use of project bank accounts. All contract payments made by the client were paid into the accounts, where the money was held on trust. Each contractor had to pay their subcontractors directly from the account, and any interest accrued was paid to the client.

- Insurance - the client took out an owner-controlled insurance programme. The core of this was a substantial contract works and third-party liability cover that indemnifies all parties involved in the central tunnelled section, including contractors and subcontractors of all tiers.

\subsection{Design and works information}

The Crossrail tunnels, civils and station contracts (Figure 3) generally operated on the basis of client design. However, some elements were designed by contractors, including sprayed concrete primary lining, reinforcement detailing, architectural elements beyond Royal Institute of British Architects (RIBA) work stage $\mathrm{D} / \mathrm{E}$, and mechanical and electrical beyond RIBA stage D/E.

The railway systems contracts generally operated on the basis of contractors designing to client performance specifications, although one exception was the client design of floating track slab.

The client divided the works information into three sections: 2A particular works information, $2 \mathrm{~B}$ general requirements and
$2 \mathrm{C}$ technical requirements. The client was quite prescriptive in its drafting of the works information, especially with regard to the $2 \mathrm{~B}$ general requirements that has 25 sections (Table 2).

Many of the general requirements had the intention of getting the contractors working at a consistently high 'world class' or industryleading level. They were also vital in passing on responsibility for compliance with relevant commitments from the register of undertakings and assurances.

\section{Commercial management}

NEC3 ECC is a contract that requires proactive management by both the contractor and the project manager appointed by the client ('employer'). It embeds processes to manage risks and agree actions and consequences as early as practicable. This approach lends itself to a complex multicontract programme such as Crossrail, but only if all parties deploy adequate experienced professional resources, processes and systems. The client recognised this challenge early on and invested in all these areas.

The experience and competence of the project manager and the team cannot be underestimated. The client created an integrated project delivery team, staffed largely from well-known

Table 2. Works Information part 2B: sections

\begin{tabular}{|l|l|}
\hline $\begin{array}{l}\text { Section } \\
\text { number }\end{array}$ & Works Information part 2B section \\
\hline 1 & Planning, environmental and traffic consents \\
\hline 2 & Undertakings and assurances \\
\hline 3 & Utilities \\
\hline 4 & Setting out \\
\hline 5 & Contractor's design of permanent works \\
\hline 6 & Incident management \\
\hline 7 & Community relations \\
\hline 8 & Network Rail interfaces \\
\hline 9 & London Underground interfaces \\
\hline 10 & Docklands Light Railway interfaces \\
\hline 11 & Assurance, records and certification \\
\hline 12 & Management and administration \\
\hline 13 & Responsible procurement \\
\hline 14 & Security \\
\hline 15 & Facilities and services \\
\hline 16 & Traffic management \\
\hline 17 & Health and safety management \\
\hline 18 & Quality management \\
\hline 19 & Environmental management \\
\hline 20 & Equipment, temporary works design implementation \\
\hline 21 & Labour relations \\
\hline 22 & Inclusivity \\
\hline 25 & Land use planning \\
\hline 25 Testing and commissioning \\
\hline 13
\end{tabular}


international project management organisations but also from direct recruitment (Tucker, 2017). This provided the enormous amount of drive and ambition at all levels that the programme required.

The client found that previous NEC experience (while beneficial) was not a prerequisite to a successful outcome - the contracts can generally be easily read and understood. What is required are competent people, experienced in major project delivery, who can adapt to and manage a variety of complex situations.

The client's governance structure (Paris et al., 2017) has allowed it to make swift decisions at a programme and project level, which is essential for a functioning delivery organisation. At a contract level the client recognised the impartiality required of the project manager to make decisions and assessments when required by NEC contracts. This was essential for the correct operation of the contracts and to meet the timescales of the contracts. The client expected the appointed project managers not only to be impartial between the parties but also proactively to make decisions and act when necessary.

The client developed a contract administration manual that gave policy and practical guidance to the project manager teams in relation to the project contracts. It helped with consistency of approach across all contracts, which was of benefit to contractors and the client. The manual continued to be updated and developed through the course of the programme to incorporate lessons learnt and any modified approaches.

NEC contracts demand a great deal of formal communication between all parties. To date over 150000 separate communications have been issued on the works contracts. Accurately managing and recording such communications was essential. The client undertook a review of all the NEC-type communication systems on the market and decided on an approach that developed linked workflows within the existing project document management system.

The great advantage of using the document management system as the foundation is that it allowed total integration of communications with the myriad of documents, reports and drawings. This approach was a considerable investment and perhaps one that only a large programme such as Crossrail could warrant. However, the system developed has been a great success, the benefits of which are wide ranging - for example archiving and historic issue investigation.

The client's project management teams were self-sufficient in commercial functions. They had all the administrative, commercial, estimating, planning and risk resources directly allocated to the project manager. Cost verification, however, was centralised under a single team as a support service to the project manager.

ECC Option C requires payment to the contractor of its actual costs on a periodic basis. The auditing of these costs is a specialist task that benefited from a dedicated team who took a consistent approach across all contracts and contractors on what can be a sensitive area. This also allowed for confidentiality of data to be maintained.

\section{Disputes and settlements}

Differences of opinion are a reality of construction contracts, especially of those as complex as on Crossrail. NEC contracts seek to make the parties reach agreement, or at least make a decision or state a final position, at the time the issue is encountered. This approach is seen as the antidote to long-drawn-out disputes running for months or years after contracts finish.

The NEC approach requires firm agreement to be made on the basis of a prospective forecast rather than a retrospective analysis of actual events. For complex issues this can be difficult to do, especially when so much is at stake and a number of issues are interwoven.

The client encountered a number of disputes with contractors, mostly revolving around issues of time, but generally engaged successfully in a process of managerial discussions to reach agreement. To date, the client has had just one formal adjudication in relation to the main works contracts.

\section{Conclusions}

Perhaps the best way to assess the success of the client's choice of contract and commercial approach (as at January 2017 and with about $80 \%$ of the central section of Crossrail complete) is to reflect on the current commercial position of the 36 main works contracts. There are 19 contracts which have reached formal contract completion, all of which are commercially settled. No completed contracts have any outstanding disputes.

Some key observations along the way have been as follows.

- With the NEC3 ECC Option C, Crossrail Limited has had full visibility of contractors' actual costs, which is a great benefit when seeking to settle disputes.

- While there are potential issues with the NEC prospective compensation event assessment approach, if the parties are able to agree as much as possible as they go, this certainly narrows any areas of difference at the final account stage. Recording positions on disputed items by those involved at the time also gives a good basis to work from. Overall, a prospective approach is beneficial to both parties.

- Full and open managerial discussions at an appropriate level are essential and are more likely to result in a positive outcome for both parties than formal dispute routes. The parties need to persevere through sometimes very difficult issues and relationships.

- The project manager, employer and contractor need to follow the processes in the contract. If one party does not, they are at a serious disadvantage in the event of a dispute.

\section{References}

Association of British Insurers/British Tunnelling Society (2003) The Joint Code of Practice for Risk Management of Tunnel Works in the UK. British Tunnelling Society, London, UK

Housing Grants, Construction and Regeneration Act 1996. Chapter 53. Her Majesty's Stationery Office, London, UK.

NEC (2013) NEC3: Engineering and Construction Contract. Thomas Telford, London, UK.

Paris R, Myatt C and de Silva M (2017) Crossrail project: environmental management during delivery of London's Elizabeth line. Proceedings of the Institution of Civil Engineers - Civil Engineering, 170(6): 49-55 http://dx.doi.org/10.1680/jcien.17.00021.

Tucker W (2017) Crossrail project: the execution strategy for delivering London's Elizabeth line. Proceedings of the Institution of Civil Engineers Civil Engineering 170(5): 3-14, http://dx.doi.org/10.1680/jcien. 16.00021 